\title{
The University Student and
}

\section{The Reference Librarian}

W

HEN I BEGAN TO WORK as a reference librarian in a large midwestern university, I had already spent several years in a great public library system, one of those people's universities where the devotion to adult education was complete and explicit and, admittedly, a little romantic. It was inevitable, I suppose, that I should have brought to my new job the prepossessions of a librarian who thought of himself throughout his experiences in circulation, reference, and research work, as an educational agent.

Yet the presumptuousness of assuming the role implicit in such a view did not prove to be mistaken. My belief in the educational definition of librarianship in general was reaffirmed by new experiences; in particular, I became convinced that when the university reference librarian stands in relation to the student as an active sympathetic intellectual figure, their encounter is a valuable educational one.

In this age of sputniks, when we Americans have been unnerved, perhaps too easily, by Soviet successes, and are vigorously, even desperately in some ways, trying to raise the intellectual level of college students, it seems to me that these remarks on the educational character of university librarianship may be timely. I should like to consider below the propriety and advantage of understanding the meeting of student and librarian in an educational framework,

$\mathrm{Mr}$. Barnett is Assistant Reference Librarian, Purdue University. treating specifically three aspects: the morale of the student, the aims of the reference librarian, and student use of bibliography.

In learning, the morale of the student is everything. In part it consists of motivation and in part of self-confidence. Yet, it is true that many undergraduates, especially the newer freshmen, who happen to stray into the university library or to have been led into it while on orientation tour, lose both. The size of the library, its physical involutions, the intangible complexities which must be mastered for use, overwhelm and even depress them. Many do not return until an inescapable assignment, a term paper or prepared speech, forces them to do so. They come back, but without heart; and sooner or later come to the reference desk for help.

It is at this point that our attitudes are crucial. The impressions we make during this brief interview will be either a confirmation of their hopelessness or the restoration of their motivation and confidence. The one acceptable course open to the librarian is the one that makes the student feel he is talking with someone who has mastered the library and that he can too for his more limited purposes achieve a proportional measure of control. The impressions we give should be those of confidence.

I do not mean we ought to "positive think" away the details and intricacies of the university library. The drudgery which attends so much of librarianship could not be hidden or forgotten if we tried. Often it comes through our work 
and shows on our faces and determines our conduct and perhaps explains the sourness seen in us by some observers.

But are not drudgery and housekeeping activities present in every profession? Does not the mechanical often precede the significant and the creative? For example, those who have done historical research know certainly that the end, the purpose, informs and makes bearable the physical labors of research.

In our own work we are able to transcend the minutiae and tedium by seeing the purpose of librarianship in an educational light. We can then appreciate the educational quality of the reference interview and are moved to make, in a profound sense, those favorable impressions that mean so much to students who, we must remember, have a high-fidelity sensitivity to the ways of adults. The effects of a sympathetic attitude cannot be overstated. This is the juncture at which generation or revival of student morale can and does begin.

The initial regard for the student and his progress in the library ought to be extended in a natural way. A follow-up would serve to create in the student a desire to continue to consult with the librarian and welcome the latter's guidance. By follow-up, I mean asking the student who is already in the search for material or examining the material that has been found, "Are you getting the information you need?" "Can you prove your side of the debate?" "Have you looked at so-and-so's article first? It is more up to date and also deals with all earlier points of view."

In a very busy reference room, a policy of follow-up has a special benefit. Frequently, the student with a question is sent, unaccompanied, by the overworked librarian to the catalog, the open shelves, or the stacks. Although this resort is in many cases inescapable, the student believes that the librarian is dismissing him. We can overcome this un- acceptable condition by supplementing the direction with a remark of this kind, "If you don't find what you want there, come back to the reference desk, we will try some other way." We, as it were, lead the student, or support him, with the strength of our promise. We make him feel that his problem is a librarian's concern and that we have related ourselves to the question of his success.

In a sense we are involved with the student in a conversation, a continuing one. This is a running conversation; we do not have time for any other. But it is a valuable educational one and I do not think it is exaggerating to say that this kind of solicitude raises the regard in which the library, librarian, and the profession are held by the student.

I want to stress how important this kind of approach is with the slow student or with those who have come to college insufficiently prepared. I mean especially many of those students who have gained entrance to many of the state-supported colleges and universities by meeting the sole requirement of graduation from high school. This practice cannot be condemned easily. More than educational policy is involved: questions of politics and tradition and even philosophy and ethics are present.

Nevertheless, it cannot be denied that many students do come to college with a poor knowledge of subjects and an incompetence in communication. They are hesitant about asking questions and do not understand abstract discourse. These are the students who are most insecure in the library. They are the ones who stand most in need of the kind of sympathetic intellectual guidance I have tried to describe. When they are in the library they have entered our domain. For better or for worse, they will have educational experiences in the library. I cannot imagine how we can dissociate ourselves from the outcomes. Even passivity to the students' educational fate 
is a response. But we have not been commissioned by our profession nor by university authorities to stand by while the ill-equipped undergraduate frustrates himself in the library. The proper course is to take the active role and thereby make more probable that the library becomes for the student the scene of successful learning.

I will say outright what has been implied. There is a pedagogy to university librarianship. The question of student motivation and confidence is a pedagogical one. To conceive of our roles in an educational way, to be concerned with the learning of students, to contemplate methods and aims, is to be concerned with principles of education. Indeed, there is a pedagogy to our work whether we have the above views or not. In the latter case it is probably a bad pedagogy, because unconscious.

What are the implications of this belief in a pedagogy of university librarianship? I think it helps us to see more clearly the unique aims of the reference librarian.

To elaborate. Quite naturally we should like the student to find the information needed to fill an assignment. This end is, as expected, set by the instructor, and both the student and the librarian must concur. Yet, the very naturalness of the aim tends to obscure the value to the student of learning skills in the methods of library use. When the emphasis is on the end product of library use, that is, the information wanted, the significance of the library as the means is overlooked. But to learn the use of the library, its reference tools, its collections, is of enormous value in the long run of a student's career. I think of it as our unique aim and $I$ am afraid that we cannot wait for the instructors to emphasize it for us.

I should not like it to be thought that I am applying inappropriately to librarianship the precept of progressive educa- tion, "we teach the student not the subject." This slogan was of value in the earlier decades of this century. It is moribund now because of the extreme interpretation which led to the vitiation of subject matter in the elementary and secondary schools. What I am saying is that unless librarians keep in view their aim that students master the library, an essential skill will be lost to these very students.

The advantages of this conception of our task is illustrated in connection with our reactions to those trivial assignments which frequently occupy the student in the library. These questions raise little enthusiasm in the librarian and this is quite understandable, especially when a picayune subject requires a lengthy search in the scrubby underbrush of the reference world. Thinking unfavorable thoughts about instructors who send students on pitiful chases, we accept the question and begin the hunt in a petulant mood. The student is caught between the shortsightedness of the instructor and the reluctance of the librarian.

But I cannot see why we let the level of our enthusiasm depend on the conduct of the instructors. We have our distinct aim as librarians and must draw our vitality from it. That the students understand the library and come to value it for its ready-made arrangement of books and the guidance of librarians is, I maintain, a purpose that satisfies and invigorates us. Indeed, our professional ethics demand that we conduct a genuine search on behalf of the student. But when, in undertaking a search, we keep before us the educational value of the method of search, then the significance of this aim will light up the activity both for librarian and student.

As a general practice, it is quite feasible to consider reference searches as opportunities to acquaint the student with the various forms of information. For example, to mention only two sources, 
largely neglected in undergraduate use of the library, the publications of the United States government and the United Nations and its specialized agencies. And, of course, these opportunities can be used to introduce the students to the highly valuable subject of bibliography.

Among the aims of library education of students, the learning of bibliography deserves a special emphasis. Sometimes one wishes that more librarians would take up the study. Not the narrow descriptive bibliography but the kind which gives control over the literature of a field or topic.

For the love of making bibliographies I am sure there is a plausible Freudian explanation and story. Why some librarians do and some do not take to bibliography seems to be a question of personality. But the social use of bibliography is quite apart from the psychological motivations of their makers.

Bibliographical knowledge leads to mastery of a subject. It cannot substitute for such knowledge although, one must confess, the temptation to make it do so it great. But in a real sense bibliography induces a more complete scholarship. I mean to say that one of the requirements of scholarship is the use of the pertinent literature of a subject or topic. By use, I mean either incorporation of the material into the research paper or thesis or project, or the rejection of it as unsound, valueless, or unrelated. To put before a student, especially the senior and graduate student, the bibliographical history of the subject in hand, is to further learning and, sometimes, the interests of truth.

The compulsion to do this verges on the moral. I cannot see any way of avoiding it. The only considerations that should make one hesitate are those of tact and timing in relation to the student whom we wish neither to antagonize by interference nor to overwhelm with bibliographical wealth.
The substantial question is how and by whom should these bibliographical riches be displayed?

I am not sure that it is necessary or even most useful to have a special course in the bibliography of a field. A course of this kind is like one in English grammar and composition, seemingly all form and no substance, a fantasy of reality. The student best learns his bibliography where he best learns his grammar and composition, that is in connection with a course where the relationship of these studies to the subject is natural and subordinate.

We find very often that instructors do not dwell on the need for securing bibliographical control as much as librarians think necessary. Yet the former almost invariably welcome the initiative of the librarian in the area of bibliography. Of course this initiative puts a greater responsibility on us. But in this way, because of our knowledge and appreciation of the value of certain forms of knowledge, bibliography in this case, we find ourselves performing an educational function and affecting the success of student learning.

The return we get may be an increased regard. But there are more definite benefits. There is the creative opportunity. We can turn to account our knowledge of books and people, our scholarship and diligence. Our work is enlivened. And while we are realizing for the students and for ourselves the educational implications of our work, we may, perhaps, be defining some of the elements of our profession.

EDITOR's NOTE: Readers of this article will be interested also in another article by Mr. Barnett, "The Professor and the Librarian: The View from the Reference Desk," which appears in the current issue of Liberal Education, $X L V$ (1959), 242-48. 